\title{
Legal Files and Empires: Form and Materiality of the Benguela District Court Documents
}

\author{
MARIANA ARMOND DIAS PAES
}

Benguela is a city with a population of around 500,000 inhabitants in the southern region of Angola. Around the Garden of Benguela's Municipal Administration (Jardim da Administração Municipal de Benguela), one of the main public squares of the city, lie many buildings that house various bureaucrats who daily perform their administrative duties. Some of these buildings are constructions from the Portuguese colonial period that survived the various decades of war that ravaged the country in the end of the $20^{\text {th }}$ century and the daily exposure to salinity due to the proximity of the building complex to the sea. The location of the buildings is not by chance. During the $18^{\text {th }}$ and the $19^{\text {th }}$ centuries, Benguela was one of the most important ports of the transatlantic slave trade. ${ }^{1}$ Following a pattern present all over the Portuguese Empire, the first centuries of colonial presence concentrated government and bureaucratic institutions in port cities. Very often, these administrative buildings would be really close to the ports themselves, as in Benguela.

One of these buildings of the Garden's complex, a newly designed one that lies besides an older Portuguese construction, houses the Benguela District Court (Tribunal da Comarca de Benguela, hereafter BDC). As in any other court around the world, the daily life of the BDC is busy. Judges, attorneys, judicial officials, and litigating parties lively move from one room to another, files under their arms, seeking to solve the many cases that flow into the Angolan judicial system. Amidst this constant flow of people and files, a room that stores paper is almost unnoticed. The BDC personnel does not access the room very often. Among antique Portuguese legal books, piles of files organized in racks call the attention. Among those files, in the higher shelves, there is a collection of late $19^{\text {th }}$ and early $20^{\text {th }}$ centuries lawsuits.

For many decades, there was no catalogue of these lawsuits. Nevertheless, some historians made use of them in their research, ${ }^{2}$ and there was even an attempt to build an inventory. ${ }^{3}$ Recently, the Universidade Katyavala Bwila, a public institution, took the lead in a joint project to organize and catalogue these legal files. ${ }^{4}$ The organization of these documents will open up a wide range of research possibilities to historians. Having this publication in sight, it is important to reflect on some aspects of this kind of documents, that is, legal files. Despite having been used by historians for many decades now, lawsuits have not yet been the object of extensive methodological reflections. ${ }^{5}$

Much has been said on the role of judges, legal officials, and courts in the making of colonial regimes. ${ }^{6}$ For the case of Spanish America, historians have even 
crafted the concept of 'jurisdictional culture (cultura jurisdiccional) to shed light on instances of normative production and administrative governance that are obscured by perspectives that straightforwardly identify >law $<$ with state.$^{7}$ They argue that in Iberian ancien régime societies, political power was identified to iurisdictio, that is, the power to determine the law (decir el derecho). According to this cultural framework, slaw « was a natural order crafted by God and should be maintained and reinforced by political powers. These conceptions placed jurists in the centre of normative production because it enhanced them with the capacity and legitimacy to define what was sthe law.$^{8}$

Thus, in the Iberian Empires, legal files were at the core of government and administration practices. Lawsuits, for example, have been, for many decades, used by historians as primary sources for historical evidence. Either in studies focussed on a 'micro-history< analysis or for the gathering of serial data, lawsuits are an extremely versatile kind of document. Some studies have a more specific focus on legal history and usually draw on them in order to analyse the production of normativities and how historical actors used courts to claim for rights. ${ }^{9}$ Less attention, however, was given to lawsuits themselves. Historians still did not give a systematic treatment to their materiality and formalities. ${ }^{10}$ Despite recognizing the role of courts in shaping a 'jurisdictional culture delve deeply into reflections on how Iberian colonial bureaucracies and legal orders were constructed by and out of legal files themselves.

In order to raise some methodological issues concerning lawsuits as primary sources, in this article, I want to argue that among the potentialities that the publication of the BDC collection catalogue will open, researchers could also engage into looking at these documents instead of just looking through them. ${ }^{11} \mathrm{I}$ do not claim to put aside social history and research focusing on how historical agents resorted to courts in order to claim for rights, in turn helping, in these claims, to shape and give new meanings to norms. What I do state is that a more complex analysis of how law was constructed through conflict and by the agency of different literate and illiterate people could include also an analysis of the form and materiality of legal documents such as the ones stored in the BDC.
To put it clear, this article does not address the usual challenges of a historical analysis focussed on the social conflicts that documents, such as the BDC's, put into light. Studies in this sense might become more frequent in the following years boosted by the publication of the collection's catalogue. What this article does aim at is to call the attention specifically to one of the many important aspects of this kind of documents, that is, their capacity to condition the ways in which judicial institutions process social conflicts. This is, thus, an analysis of the processes of institutional construction materialized by formalities, not of the content of the social conflicts themselves. In this sense, it intends to point out analytical possibilities by engaging into the discussions this special issue raises on the production of files and their role in the daily life of institutions.

In the last years, anthropologists and social scientists discussed on how documents are not only products of bureaucratic and administrative institutions but are actually constitutive of bureaucracies themselves, of their practices and their knowledge. This literature argues that documents have long been overlooked because researchers used to see them only as repositories of information, as a way to access the reality that was their actual object of interest. Documents and files are, however, more than just objects representing reality; they play a mediation role that shapes and defines the boundaries of social actors' agency. ${ }^{12}$

In this sense, files are seen as raw materials of power,${ }^{13}$ as objects that have an active performative role in shaping and constituting power relations and structures. Some of these power relations and structures are shaped by documents that intend to express struth. In order to do so, to be taken as evidence, they must comply with certain formalities and acquire specific material aspects. In this sense, these formalities and material aspects are not neutral. They actually shape and conform the content of what is inscribed on files. The information that they claim to contain as an expression of reality is, in fact, translated and distorted in different and specific ways. ${ }^{14}$

Files and paperwork thus mediate relations among people in broader terms than the reductionist assumption that they are mere tools for governments' control over population. Habits of documenting actually penetrate the everyday life of individuals, shaping the 
forms that some social relations will take and orienting people's agency. Therefore, taking the formalities and material aspects of documents seriously can elucidate important aspects of repetitive practices and routine procedures that might actually play a more important role in the sproduction of truth than the actual content of files. The struth of documents is not necessarily a result of their capacity to accurately express reality, but of their compliance to certain procedures. ${ }^{15}$

This constitutive character of files and paperwork is also noticeable in what specifically concerns legal files. ${ }^{16}$ It is not possible to understand law by putting norm and reality side by side in a dichotomy that disregards the mediating role of legal files. Files are the mediators that translate real experiences and conflicts into a legal language that transform reality into law. In case a legal file is filed, whatever happened to people involved in the conflict must now be proved. This proof is often made through a series of documents and testimonies that sive confidences, that supposedly attest the external fact. When all these documents come together in a lawsuit, the file attaches them together, enhancing them with slegality،. The procedure chains and shapes reality to the language of law. Legal files thus profile, shape, and format reality. Therefore, they are not merely containers of information about the facts. What legal files actually do is to format reality. And they do this following specific rules in what concerns their form and materiality. ${ }^{17}$

Hence, the legal files stored in the BDC also follow specific rules in what concerns their form and materiality. The collection comprises an array of petitions, mandates, ownership titles, certificates of registration, tax receipts, powers of attorney, communication between judges and judicial officials from different jurisdictions, and so on. The core of the collection, however, are the lawsuits. Approximately 2,100 lawsuits were filed between 1850 and $1950 .{ }^{18}$ There is no information on the formation of this collection and on what happened to the lawsuits filed before 1850. These legal procedures were filed before the jurisdictions (juízos) of Benguela, Luanda, Caconda, Quilengues, Dombe Grande, Catumbela, Lobito, Mossamedes (nowadays Namibe), Novo Redondo (nowadays Sumbe), Lisboa, and Porto.

Accepting the challenge put by this special issue, the material and formal aspects of these legal files, stressing their role as mediators that actually shaped and transformed the content of the information they hold. Also, I suggest that the reiterated practices that historical actors engaged for the production of these documents played an important role in shaping their daily agency and in the making of Portuguese colonial legal order.

\section{Law, Courts, and Legal Files in the Portuguese Empire}

Historians have long stressed that the Portuguese Empire was not a continuous and monolithic enterprise. One of its main characteristics was discontinuity, both geographically and administratively. It acquired different shapes depending on the concrete historical conditions that it faced. The stress on the complexity of the modes of governance in the Portuguese Empire thus led many historians to focus on the actual local practices of governance. By shifting the focus from the central government to speriphery powers،, they shed light on the diverse array of institutions and actors that organized colonial societies. ${ }^{19}$

In what concerned the administration of justice in West Central Africa, historians highlighted how Portuguese colonial authorities interacted with local political powers especially in what concerned the relations between law and practices of enslavement. The coexistence of multiple normative orders in this territory added complexity to the legal framework. Signing vassalage treaties facilitated the spread of Portuguese colonial power and colonial institutions in the regions of the so-called 'Kingdom of Angolar and 'Kingdom of Benguelar. Yet, these treaties often guaranteed - to some extent - that the administration of justice would continue in charge of local authorities - sobas and macotas - and would continue deciding according to local practices and norms. Nevertheless, over the centuries, there were numerous conflicts and disputes over jurisdictional powers between Portuguese and local authorities. ${ }^{20}$

During the $19^{\text {th }}$ and $20^{\text {th }}$ centuries - the period that the BDC collection covers - Portuguese judicial institutions were never able to reach all corners of the so-called 
>Province of Angolar. In these decades, numerous reforms on judicial organization took place, and they were often preceded by reports stressing the difficulties colonial administrators faced in administering justice and enforcing Portuguese norms and judicial practices throughout the whole territory. The difficulties the reports point out range from the suncivilized ‘ character of local populations to the bad training and poor education of colonial officials. ${ }^{21}$

Nevertheless, even assuming the coexistence of multiple normative orders, the precariousness of Portuguese judicial institutions in the colonial territory, and the poor capacity - often the lack of willingness - to apply Portuguese norms and practices to local populations, it is not irrelevant that these colonial legal institutions existed in these societies. During the approximately five centuries that Portuguese colonialism lasted, ships daily crossed the oceans carrying, from one colonial jurisdiction to another, lettered jurists who travelled in order to take over offices in American, African and Asian colonial territories. The agents of the Portuguese Crown regularly moved between jurisdictions due to a system of temporary nominations to offices in colonial administration. Lettered jurists occupied a relevant amount of these offices, especially the ones higher up in the hierarchies. In the context of multiple normativities and competing jurisdictions that characterized the Portuguese Empire, theselettered jurists were fundamental for managing this legal patchwork. To do so, they took with them their personal libraries, administrative files, letters and recommendations that would instruct the performance of their duties. ${ }^{22}$

Moreover, the handling of paperwork and the production of legal files was not restricted to lettered jurists. A wide stratum of $>$ non-lettered administrative personnel daily administered and processed them. ${ }^{23}$ In Iberian colonial societies, notaries, scribes, and parish priests also played a fundamental role in the daily production of documents that were not mere instruments or products of colonial administration, but rather constructed administrative knowledge and practices that allowed the pervasiveness of colonial domination. ${ }^{24}$

This personnel had specific normative conceptions and ideologies. The institutions they formed had specific legal rules in what concerned procedures.
And they mattered. Despite many political forces and interests entangled in legal matters and judicial controversies, in order to legitimize itself, law must comply with its own rules and formalities. Thus, even when explicitly following personal, political, or class interests, jurists, and legal officials must do it in the shape predetermined by legal norms and practices in order to enhance their acts with efficacy. Furthermore, in many cases, these jurists and officials truly believed in this set of rules and ideological rhetoric. ${ }^{25}$ Thus, the assumption that colonial legal orders were precarious and not hegemonic should not prevent scientific analysis that deal with legal files to take seriously their role in shaping people's agency.

The existence of Portuguese colonial institutions in West Central Africa mattered because people actually resorted to them. African populations often made use of Portuguese colonial institutions in order to solve their conflicts. One example is the codex (códice) 7182 of the Angola National Archive (Arquivo Nacional de Angola, from now on ANA). It contains a protocol book of petitions directed to the General Governor of Benguela between 1826 and 1829. It shows that Africans resorted to the General Governor in order to solve disputes concerning debts, witchcraft practices, and enslavement practices, among others. The General Governor himself decided some of these conflicts, and others he forwarded to the competent judges. ${ }^{26}$ The BDC legal files collection also reveal that Africans resorted to Portuguese courts in certain cases. ${ }^{27}$ It is obvious that the access to Portuguese courts and other administrative institutions depended on many factors, and not all Africans had the possibility to resort to them. Most probably, the ones who did were among those who were somehow familiar with colonial institutions. Despite the obstacles they might have faced, the fact that some of them could and actually did resort to Portuguese judicial authorities reinforced the power of Portuguese colonial legal order. ${ }^{28}$

Apart from resorting to Portuguese colonial institutions in order to solve their disputes, people who did not hold administrative offices engaged in document and file production. ${ }^{29}$ They knew that the creation and recognition of rights could highly depend on these pieces of paper. They were aware that paperwork did not only materialize rights but also constitute them. ${ }^{30}$ One example of this paperwork production can be 


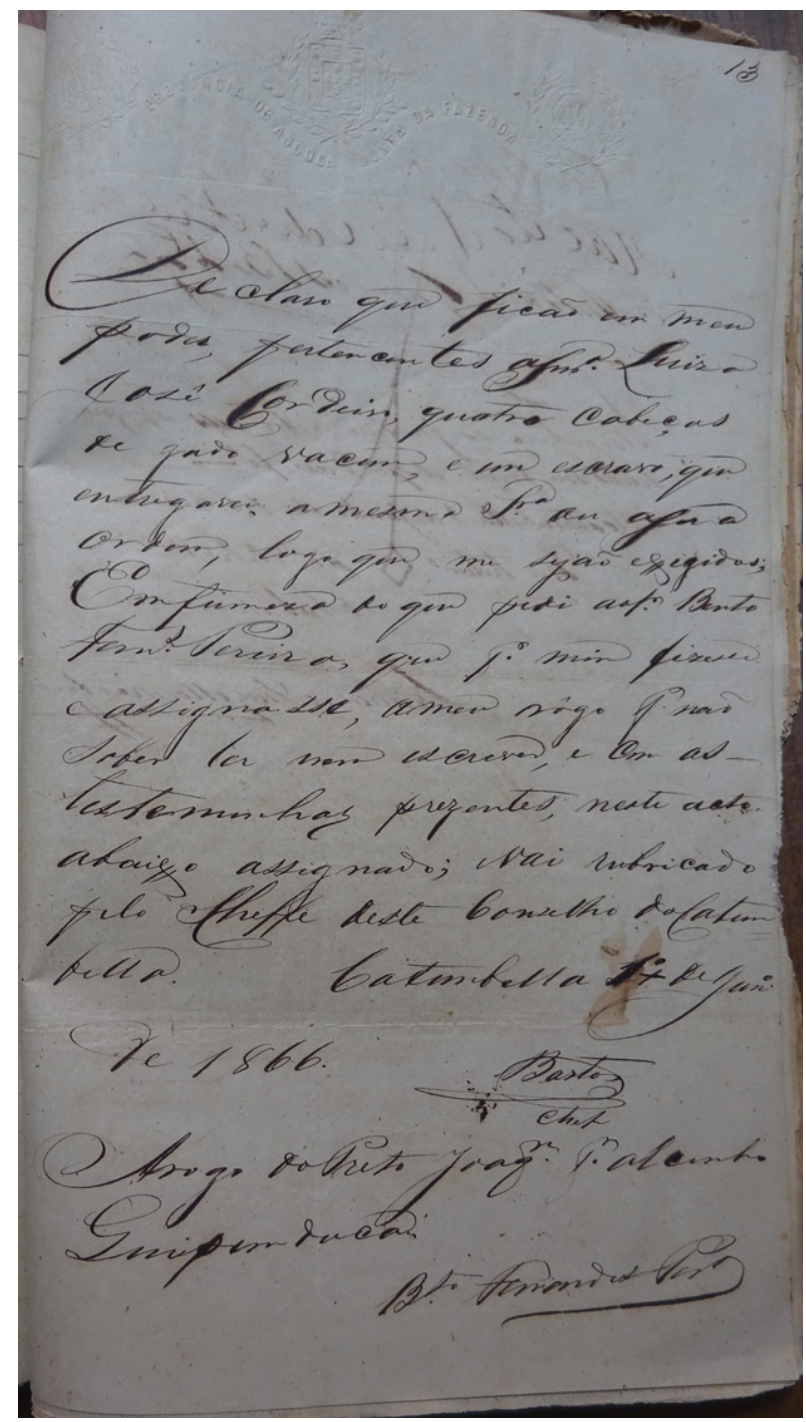

Figure 1: Written Promise on high relief paper and signed by the Chief of Catumbela Council (Source: Benguela Provincial Court, 1866, Autos cíveis de depósito de duas libertas de nomes Bibiana Catumbo, e Theresa Caleço, a requerimento do Curador dos escravos e libertos, p. 13).

found in one 1866 case of the BDC collection. ${ }^{31}$ In this lawsuit, Luiza Cordeiro Bimbi was accused of illegally enslaving two free women. To defend herself against these charges, she claimed that the women were former slaves of Joaquim Quinpunduca. ${ }^{32}$ The judge demanded Luiza to declare the title she had over the slaves. She then presented two documents: a written promise made by Joaquim that he would deliver four cows and one slave to Luiza and a certificate of a conciliation hearing in which Joaquim promised to deliver four cows and in

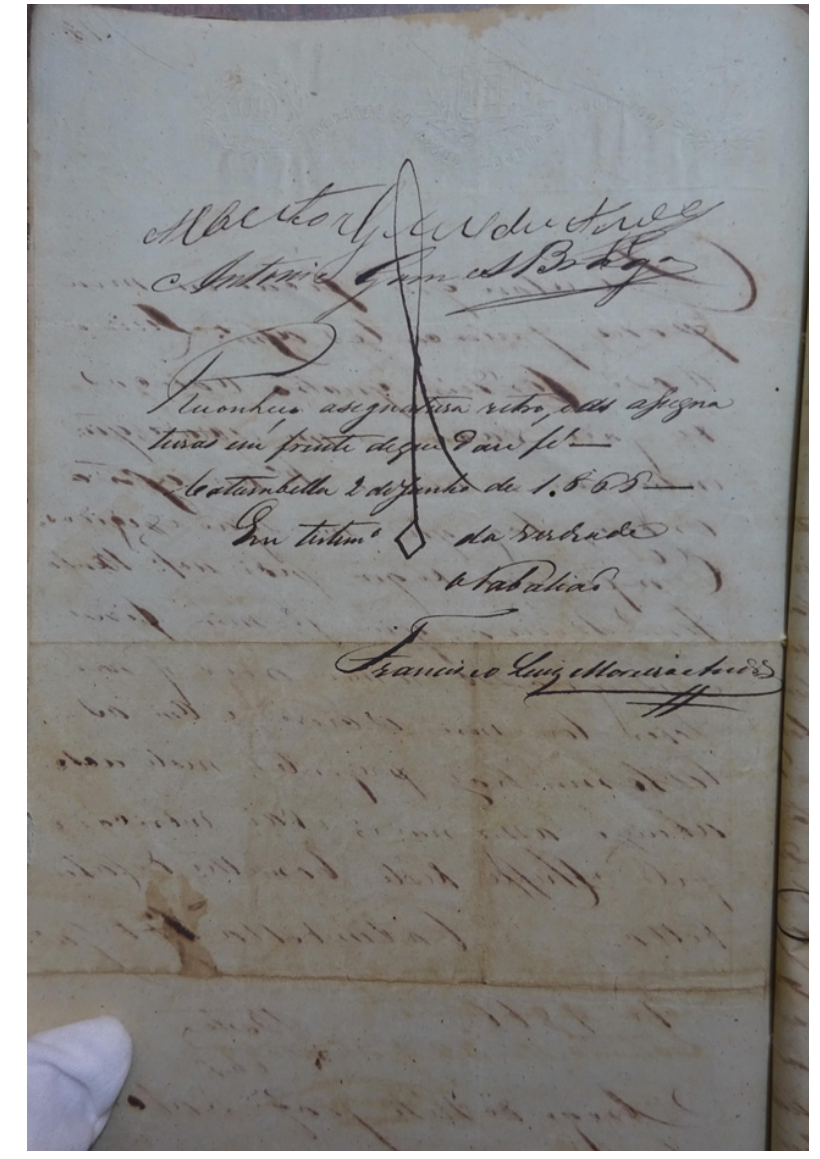

Figure 2: Written Promise on high relief paper and signed by the Chief of Catumbela Council (Source: Benguela Provincial Court, 1866, Autos cíveis de depósito de duas libertas de nomes Bibiana Catumbo, e Theresa Caleço, a requerimento do Curador dos escravos e libertos, p. 13v).

The first document, the written promise, was on letterhead paper with a high relief of the Treasury Board of the Province of Angola (Junta da Fazenda da Província de Angola). It was also signed by the Chief of the Catumbela Council (Figs. 1 and 2). Both the letterhead paper and the signature of a colonial authority - indicate that the parties were trying to endow their promise with certain sofficiality،. Also, ratifying the promise at a court hearing could be a strategy for making it more authoritative.

In their transaction concerning the alleged slaves, Luiza and Joaquim engaged in the production of documents which they tried to endow with some authority. This indicates that they might have been aware that documents which followed certain formalities and embodied particular material aspects 


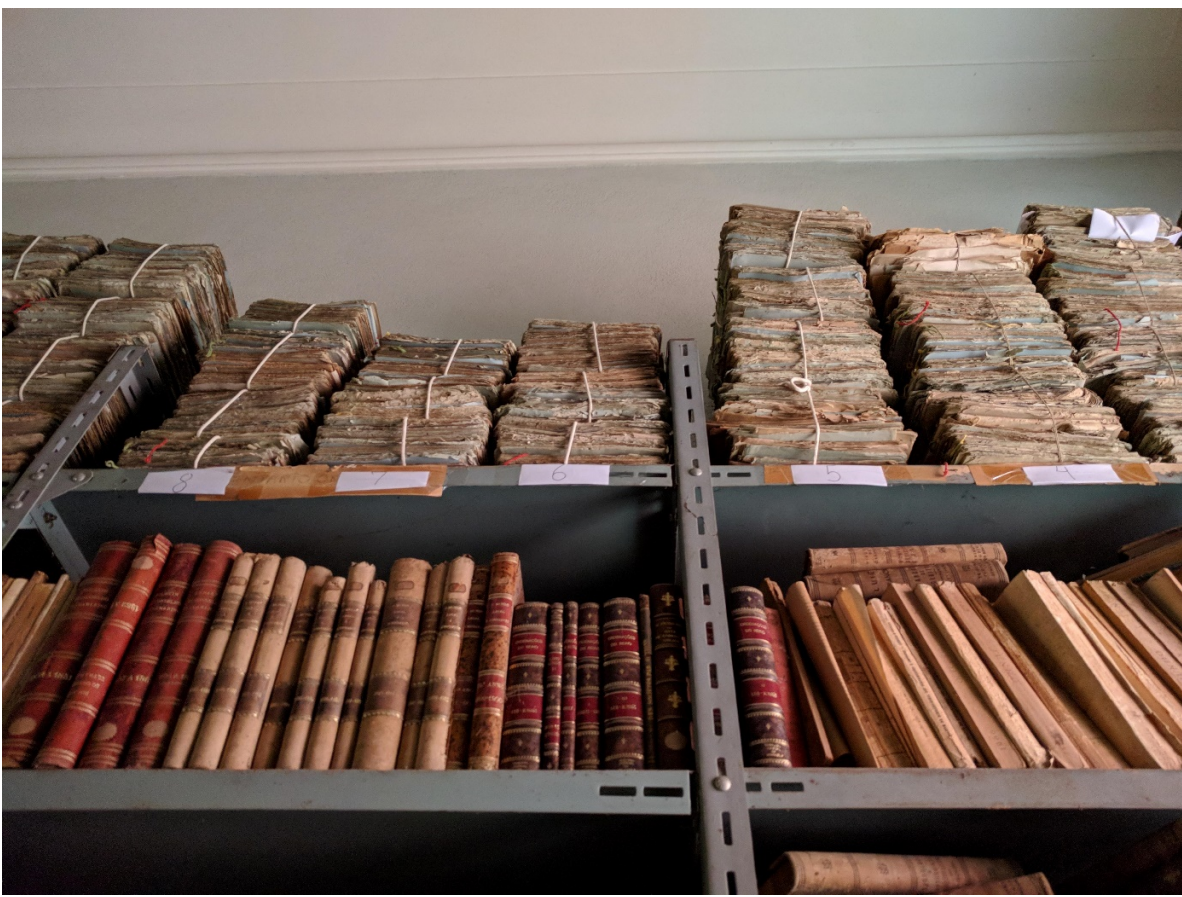

Figure 3: Lawsuits and legal books in Benguela District Court (Source: Photograph by the author).

could create and guarantee rights. Most probably, when they created these documents, they did not know that the two women who were the actual objects of transfer would later contest their slave status in court. Nevertheless, Luiza and Joaquim decided to formalize their negotiation in paperwork that would acquire authoritative power by incorporating material aspects such as letterhead paper and the signature of a colonial official. Even not knowing exactly what were the formalities that official documents should comply with in order to be legally valid, people had an idea of what kind of material aspects could turn paperwork into evidence. This vernacular knowledge thus shaped the way they conducted their daily transactions and negotiations.

\section{Form and Formalities in the Portuguese Empire}

In the Portuguese colonial legal order, form and content were intertwined. ${ }^{33}$ Hence, the analysis of norm production should focus on both of them. Analogously to the Spanish legal framework extensively analysed by culture «, the premise of Portuguese normative architecture during the Early Modern period was the existence of a natural and divine order that governed the world. Not only persons and material things were subject to this natural order. Also, immaterial things - as, for example, sentiments and colours - were entangled in norms and regulations. Formality was paramount for this normative framework. Following the rituals, adopting the symbols, reproducing formulae was crucial to the fulfilment of the natural legal order in ancien régime Portuguese society. In this context, formalities played almost a religious role. Their performance had the capacity to guarantee the solemnity required by legal acts. ${ }^{34}$

Legal files in general and lawsuits in particular were completely immersed in these conceptions. Petitions, for example, should follow really strict formulae. Often legal books - the so-called slegal doctrine - were the vehicles of these structural rules that informed legal files. It is thus not by chance that in the same small room of the BDC, we can find both legal books and legal files, side by side (Fig. 3).

Many legal texts were produced during the early modern period with the goal to instruct jurists, other government officials and claimants on the norms 
and formulae they should follow when initiating or processing a judicial claim. ${ }^{35}$ This way, these legal books participated in the process of enforcing colonial authority through the production of paperwork and files that followed predetermined formalities. ${ }^{36}$ Recent scholarship also investigates the so-called pragmatic legal literature, that is legal texts produced for a nonlettered audience, such as alphabetical collections, instructions concerning procedures, manuals to notaries, case compilations, and so on. This scholarship stresses that this genre of legal literature played a central role in spreading certain normative practices in the peripheries of the Iberian Empires. ${ }^{37}$

A very popular text that circulated in territories under Portuguese jurisdiction was Gregorio Martins Caminha's »Tractado da forma dos libellos«. The book was first published in 1549 and was reprinted many times during the centuries that followed. As is relatively common until today, ssuccessful legal books would have many editions over the centuries. These new editions often brought adaptations of the original text to current legislation and jurisprudence. In the case of Caminha's "Tractado", its many editions reached the $19^{\text {th }}$ century, when José Homem Corrêa Telles, another well-known Portuguese jurist, published an edition of the book with commentaries that adapted it to current legislation. Through these radaptations،, form prescriptions created in the early centuries of Portuguese colonialism could endure for many centuries, shaping the ways according to which conflicts should be translated when they reached colonial courts. ${ }^{38}$

As many other books, the purpose of the "Tractado « was to present models (formulários) that would instruct people - parties and lawyers - on how to file a petition in Portuguese courts. The importance of formalities and formulae is present in the materiality itself of the book. For example, in the first page of the book, the expression "Begins the form " (Começase a forma) is highlighted by its size and its position in the page (Fig. 4).

Apart from judicial initial petitions (libelos), the book also offered models to produce other kinds of judicial acts such as defences, appeals, sentences, and so on. Also, there were models for contracts and powers of attorney. This variety indicates that the target of the author was a wide public, ranging from high-ranking

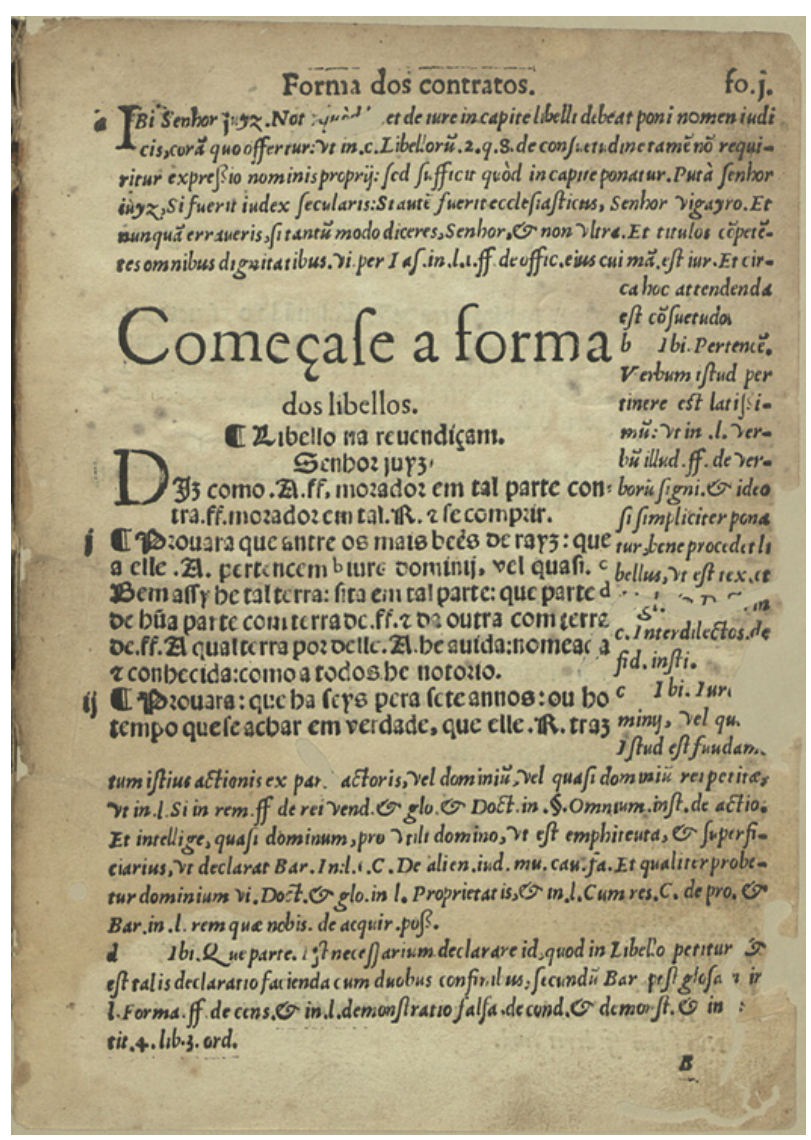

Figure 4: Highlight of the expression sBegins the form in the first page of the book (Source: Caminha, Gregorio Martins, Tractado da forma dos libellos e da forma das allegações iudiciaes e forma de proceder no iuyzo secular \& ecclesiastico e da forma dos cõtractos com suas glosas \& cotas de dereyto, feyto pello licenciado Gregorio Martiz Caminha, Coimbra: Antonio de Maris 1558, p. 1).

to local farmers who wanted to make contracts of land lease.

The production of books that diffused models that should be followed by people who accessed Portuguese colonial judicial institutions lasted in the $20^{\text {th }}$ century. For example, in 1920, Roberto Fonseca published the "Manual prático do serviço judicial para chefes dos postos de polícia das circunscrições administrativas da Província de Angola" in Lisbon. The original manuscript of the book can be found in the ANA. It was handwritten by the author in a notepad. More than half of the manuscript are models to judicial acts such as petitions, defences, sentences, and so on. There was no information on when the handwritten version of the 
manuscript was produced. Nevertheless, it attests that reiterating formalities in order to translate reality into legal language was a practice that persisted in the realm of Portuguese colonial administration far into the $20^{\text {th }}$ century. ${ }^{39}$

It is evident that not all daily transactions or litigation happened inside the frameworks established by Portuguese jurists and norms. However, all over the Empire, people who lived under Portuguese jurisdiction knew that complying with these forms could be a way to ensure their rights in a potential conflict with neighbours, family members, commercial partners, and so on. This pervasiveness of forms and formalities was fundamental in the making of Portuguese colonial domination. Similar patterns of documents and legal files can be found all over territories subject to Portuguese jurisdiction. The ubiquity of some formal patterns was so intense that they survived colonial dominance. Brazil, for example, declared independence in 1822. However, even after its independence, many legal files continued to be produced with the same formulae as the former Portuguese ones, reproduced also on the other side of the ocean, in the legal files stored in the BDC. Take, for instance, the powers of attorney. The same patterns and formulae (e.g. the opening statement "Saibão os que este público Instrumento de Procuração bastante virem [...]«) were followed in cases filed before Benguela and Rio de Janeiro courts (Figs. 5 and 6).

During the $19^{\text {th }}$ century, after Brazilian independence, printed models of powers of attorney became popular in court cases. Their similar design in Benguela's and Rio de Janeiro's court cases is noticeable (Figs. 7 and 8). At first glance, this design similarity might seem trivial. Nevertheless, as the lawsuit collections of the BDC and of the Brazilian National Archives (Arquivo Nacional) attest, many different kinds of legal acts such as the cover of the procedures, judicial mandates, transcriptions of witnesses' testimonies, petitions, notary certifications, and so on - had similar material characteristics and followed analogous formalities and formulae on both sides of the Atlantic. Thus, the materiality of legal files attests that reiterated and deeply rooted administrative practices persisted even after Brazilian independence from Portugal, which indicates the pervasiveness and persistence of colonial

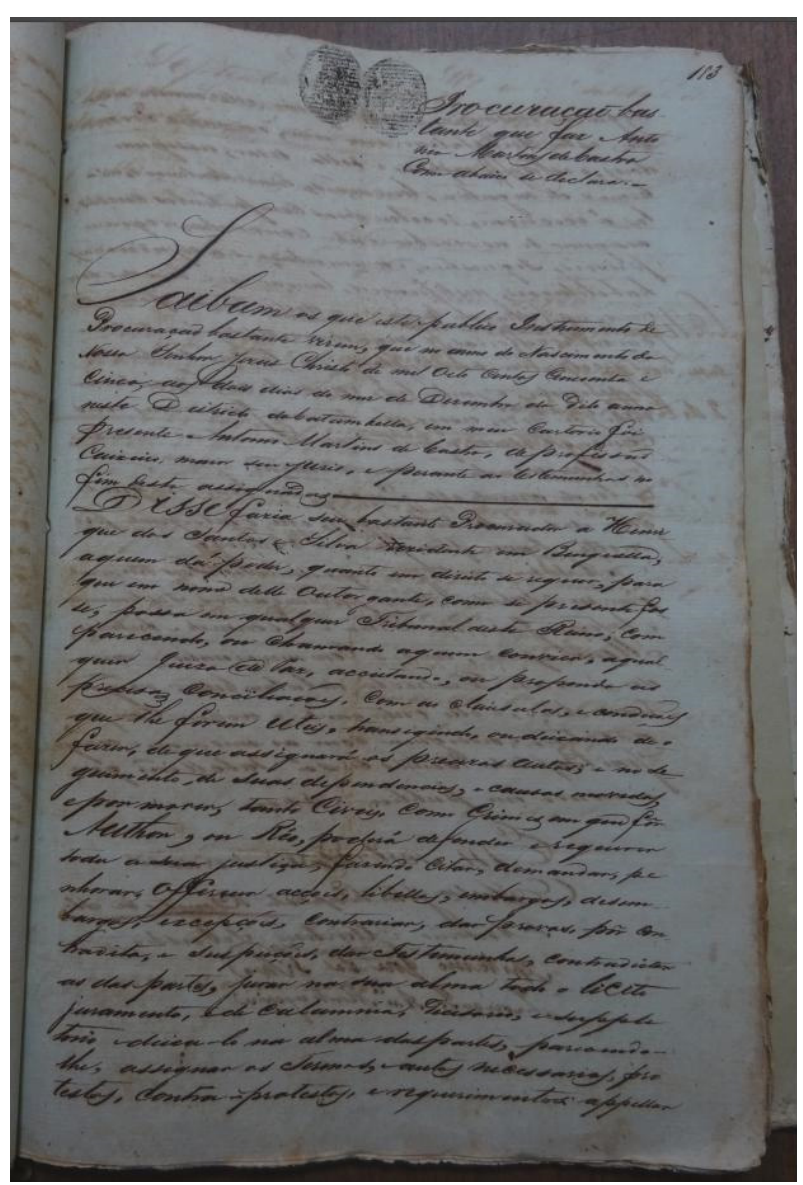

Figure 5: Manuscript power of attorney in Benguela court (Source: Benguela Provincial Court, 1857, Autos de reunião de Concelho para cobrança, digo, de chamamento de Credores, e reunião de Concelho de família do Casal de Lourenço Fernandes Martins, p. 113).

and daily engagement of both colonial officers and local populations in the production, reproduction, and dissemination of paperwork that followed predetermined formalities.

\section{Form, Content, and Social Conflict}

In Portuguese jurisdictions, form considerably shaped content in legal files. The legal files of the BDC collection are an example of how formalities and formulae had the capacity to shape and condition the ways in which colonial courts would access conflicts brought before them. Formalities and formulae had the capacity to both define the boundaries of social actors' agency and frame 


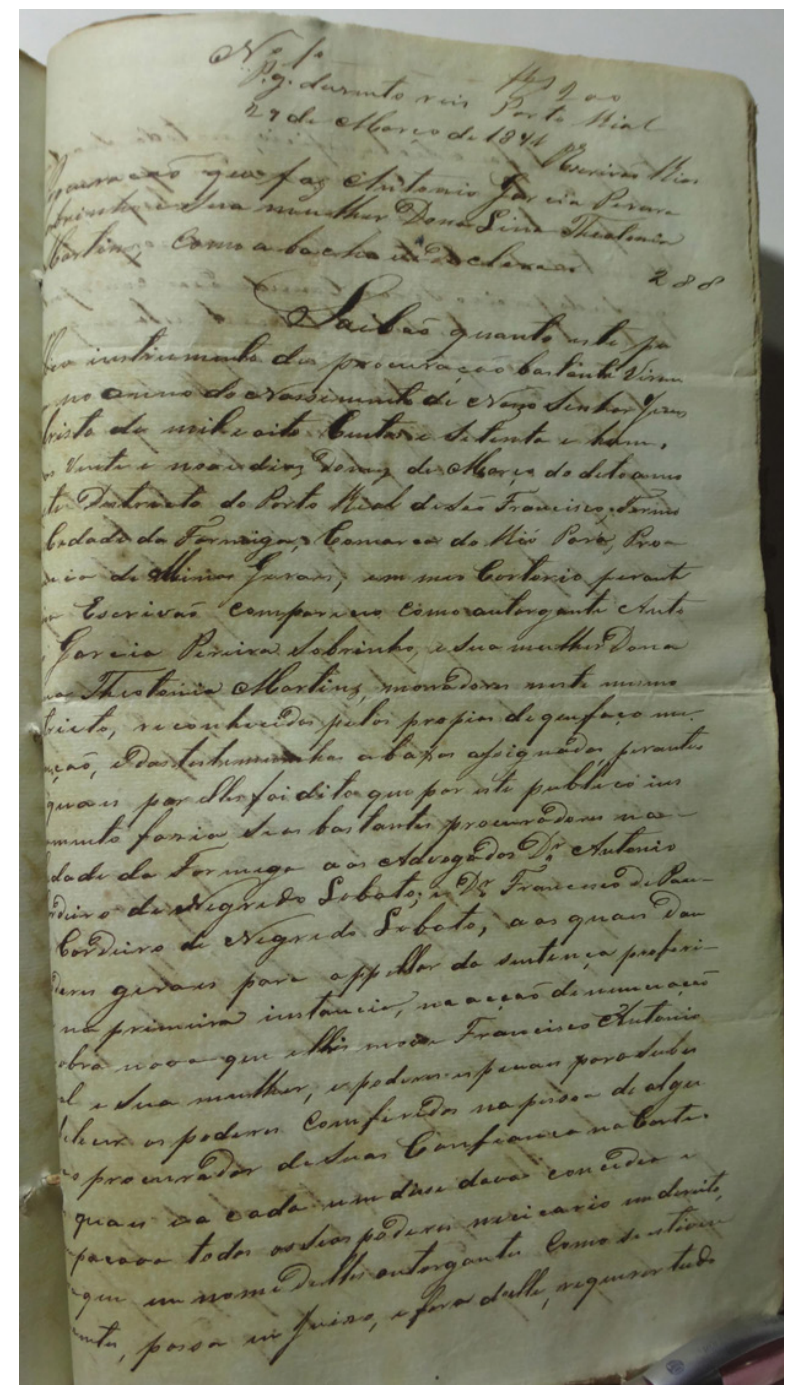

Figure 6: Manuscript power of attorney in Rio de Janeiro court (Source: Arquivo Nacional, Relação do Rio de Janeiro fundo 84, série apelação cível ACI, código de referência 84.0.ACI.08260, apelante Francisco Antônio Leal, apelado Antônio Garcia Pereira Sobrinho, ano inicial 1865, ano final 1872, número 7.250 , caixa 388 , galeria $C$, local Formiga, p. 288).

reality in a specific legal language. In the BDC collection, lawsuits concerning land disputes are an example of this complex relationship between form and content in legal documents. Let's analyse, for instance, the revindication lawsuit filed by Manuel Cassador against Dona Julia Martins de Sant'Anna. The plaintiff's lawyer structured the initial petition (libelo) ${ }^{40}$ in paragraphs, which was the usual pattern in this kind of judicial act.

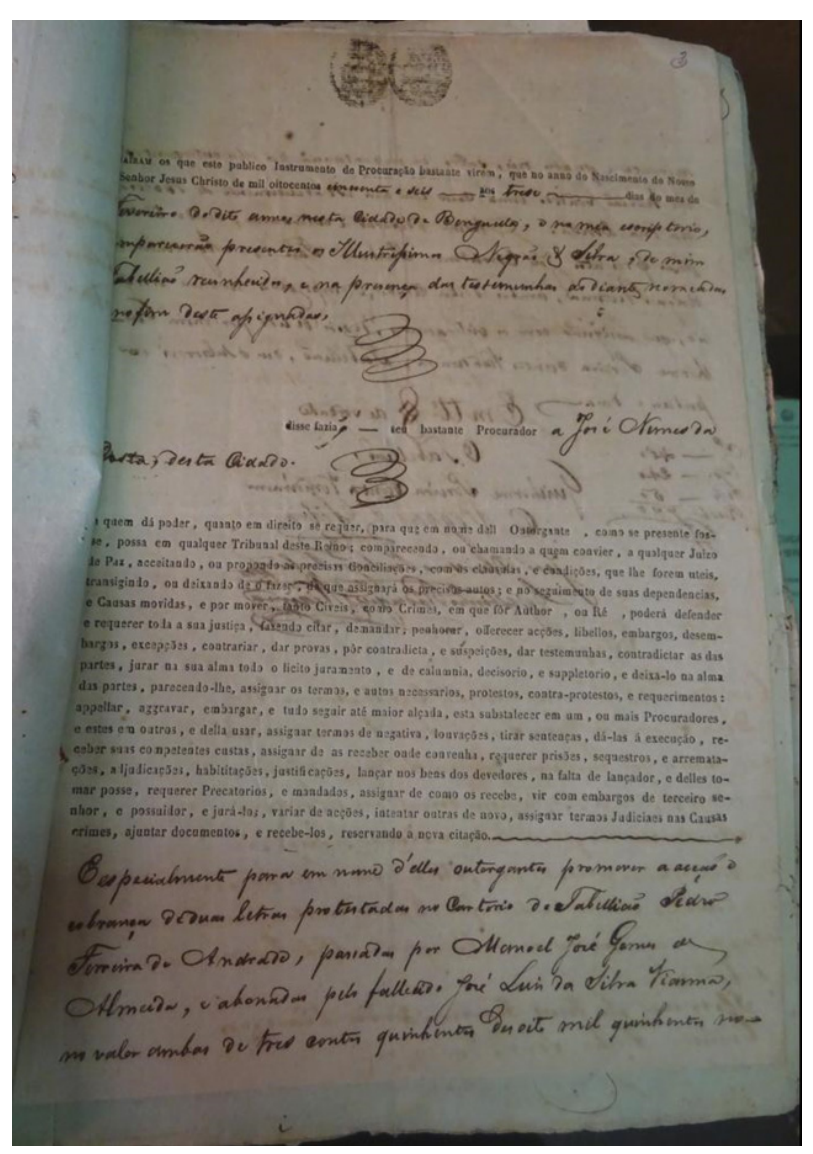

Figure 7: Printed power of attorney in Benguela court (Source: Benguela Provincial Court, 1856, Autos civeis de ação commercial entre partes AA Negrão e Silva RR Dona Theresa de Jesus Ferreira Torres Vianna, Viuva Meeira e Tutora dos filhos de seu fallecido Marido José Luis da Silva Vianna, p. 3).

1. The plaintiff was the son and only heir of Marcella de Suião, deceased in 1857.

2. His mother owned four slaves and a piece of land (arimo) situated at Catumbela district, on the margins of the river, in a place called Quitubo. In the piece of land, there were a building (cubata) and plantations of palm trees, corn, sugar cane, and bananas.

3. In 1848, the defendant's lover (barregão) took possession over the four slaves and enslaved free people claiming that the reason for this was a supposed debt of the plaintiff's brother, who was already dead himself.

4. In 1855, the defendant also took possession over the piece of land because of this alleged debt. 


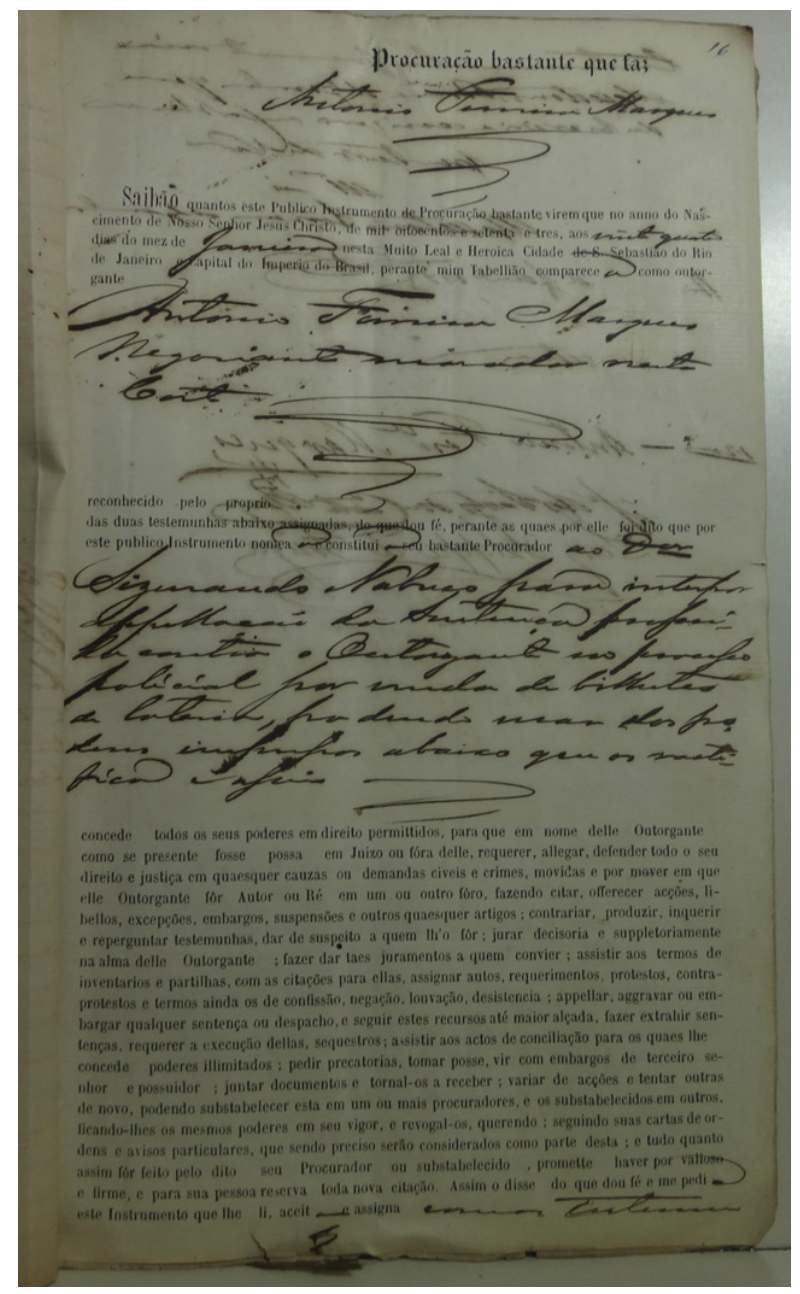

Figure 8: Printed power of attorney in Rio de Janeiro court (Source: Arquivo Nacional, Relação do Rio de Janeiro fundo 84, série apelação criminal ACR, apelante Antônio Ferreira Marques, apelada A Justiça, ano inicial 1873, ano final 1873 , número 83 , maço 161 , galeria $C$, local Rio de Janeiro, p. 16).

5. After this illegal possession acts (esbulho), the defendant asked the Chief of Catumbela (a colonial official) to call the plaintiff and his mother in order to give them a certificate that the debt was paid.

6. The Chief of Catumbela asked a notary to prepare the certificate, but the plaintiff and his mother refused to receive it because they did not recognize the debt.

7. The Chief of Catumbela obliged them to receive the certificate, menacing them with imprisonment.

8. The plaintiff's mother left the certificate in Catumbela and went to Benguela in order to claim for her rights.
9. The plaintiff's mother could never claim for her rights because she lacked monetary resources and got ill.

10. With his mother's death, the plaintiff could claim for the property that was his legitimate inheritance.

11. The defendant still had possession over all property, except for one slave that she had sold.

12. The defendant took possession over the plaintiff's property without valid title.

It is not by chance that Manuel's arguments followed this structure. It complied with the elements present in legal books concerning the patterns which judicial petitions should follow. For example, in his book, Caminha structured judicial initial petitions (libelo) on revindication cases containing the following elements:

1. The name of the plaintiff, his or her place of residence, and the name of the defendant.

2. Plaintiff's statement that he owns the contested piece of land, indicating its geographic location.

3. Description of the illegal occupation or usage of the land by the defendant, stressing the approximate date when these acts began and stressing that they were conducted without title and just cause.

4. Asserting that there were previous extra-judicial attempts to solve the conflict.

5. Affirming that all these allegations were public and notorious.

6. Requesting that the judge declared the plaintiff as master (senhor) of the piece of land and that the sentence condemned the defendant to restitution.

The requirement to fit legal arguments into formalities and formulae previously established, as the ones detailed in Caminha's "Tractado", determined the kind of stories parties told in lawsuits. In the specific case of revindication lawsuits' formalities and formulae, the story should consist of a dispute between two identifiable parties over a determined piece of land that one of the parties occupied without good faith and just title. It would also enhance the chances of having a favourable decision whether the narrative stressed that extra-judicial attempts to solve the conflict took place and the whole story was public and notorious. This is the format a story over a social conflict was supposed to have in order to fit into a judicial procedure. Thus, 
predetermined legal formalities ended up reducing the immeasurable diversity of real land disputes to highly specific facts.

The structure of the narrative that Manuel presented in his initial petition complied with the elements present in the Caminha's model. As in this case, many other lawsuits and legal files conformed to reiterated practices that articulated facts in specific ways transforming them into adequate legal arguments. The relationship between lawsuits such as Manuel's and books such as Caminha's enlightens the process in which these two kinds of legal paperwork engaged in the construction of law and colonial legal regimes. Legal files and legal books constantly referred to one another in a process of legal intertextuality ${ }^{41}$ that formatted reality, turning it into legally relevant content.

During the $19^{\text {th }}$ century, Portuguese jurists engaged in numerous discussions about the administration of justice in colonial territories. ${ }^{42}$ This was a time during which liberal conceptions of law became hegemonic among Portuguese jurists. Liberal law had different ideological foundations than the ones of ancien régime ius commune. Nevertheless, formality kept on playing a significant role in perpetuating practices among jurists and judicial officials. What was different then were the ideological justifications to comply with these formalities. Now, following the rites and forms was a way to guarantee security and impartiality of legal procedures.

A relatively common kind of legal procedure in the BDC during the last decades of the $19^{\text {th }}$ and and first decades of the $20^{\text {th }}$ century was the smere possession justifications` (justificação de mera posse). In a preliminary analysis, I could identify 40 of these lawsuits, filed between 1888 and 1919. ${ }^{43}$

Possession was the main way to acquire and secure land rights in Iberian societies during the early modern period. Both Portuguese and Spanish interpretations of ius commune categories and norms favoured the exercise of possession over other manners of ownership acquisition. Title registration was not systematically employed in the Iberian Empires jurisdictions during these centuries, and, in fact, title deeds did not guarantee rights when confronted with possession situations. Land titles existed, but they did not have any judicial strength legitimize these titles. Also, possession claims very often overruled titles claims in court litigation. ${ }^{44}$

This scenario, however, fundamentally changed during the long $19^{\text {th }}$ century. Liberal legal theories defended that property was an absolute right and that in order to secure it, titles should identify and individualize the owners. Due to its absolute character, property right was then at the top of a hierarchy of rights over things and could hardly be overruled by possession. Obviously, possession claims continued to exist. But possession was intensely marginalized and lost the strength it once had before title deeds. Registration and the issuance of title deeds were also part of a broader development of the formation of nation states. During the $19^{\text {th }}$ century, registration and land demarcation were some of the measures that rising nation states conducted in an attempt to identify and control their territories and populations. ${ }^{45}$

In this context, Portuguese jurists that were taking the lead of liberal reforms in property law, created what they called >mere possession registration`. This registration was presented in articles 523-526 of the 1867 Portuguese Civil Code. The Code defined spublicity، in possession situations as registration, a radical change in relation to the previous ius commune system. A change that expressed the goals of the liberal property reforms. Article 523 stated that "public possession is the one which has been rightfully registered or which has been exercised in a way that can be known by interested people«. >Mere possession` registration, in turn, could take place in cases when possession had been exercised for more than 5 years in a peaceful and public manner. It was necessary that a judicial justification procedure preceded the registration. This judicial procedure was the $>$ mere possession justification ${ }^{4}{ }^{46}$

In an aleatory sample of 26 >mere possession justifications s that are part of the BDC's collection, ${ }^{47}$ all follow the same pattern of initial petition. The petitions open with a statement of the plaintiff affirming that he was the legitimate owner and possessor of a piece of land for more than 5 years. A description of the approximate limits of the piece of land followed. The plaintiff then asserted that this possession was continuous, public, and pacific and continued describing the possessory acts that would characterize the possession. At the end, the plaintiff asked the judge to declare his possession 'justified 
In a similar way as models did, the reiterated patterns that these initial petitions followed restricted the content of the legal claim. All the conflicts and peculiarities that the real situation involving the claimed pieces of land might encompass were reduced to a few formal elements. These elements were later discussed during witnesses' hearings. Inside the courts, there was very little space for other elements of the social conflicts. The similarities among these lawsuits go beyond formalities and the usage of certain formulae in the initial petitions. The design pattern of the initial petitions and of the following legal acts is an equally recurring feature.

Throughout the whole period that the collection of the BDC encompasses, formalities and materiality played a central role in framing the narrative of conflicts that reached Portuguese colonial authorities. The structure of these formalities, the design of the material artefacts, and the ideological grounds of these procedures changed during the period covered by the documents. A privileged characteristic of this collection is the time frame the legal files cover: second half of the $19^{\text {th }}$ century and the first half of the $20^{\text {th }}$ century. In this period, the region experienced deep transformations: the spread of liberalism and the consolidation of capitalist economic production happened hand in hand with a process of deep legal reforms. The justification and ideological ground of Portuguese normativities was no longer the existence of a natural order. Jurists then started arguing that individuals and their subjective rights were the foundation of legal regimes. In this new framework, the role of formalities and formulae was no longer to secure the divine character of law, but to ensure that following predetermined procedures would guarantee litigants' individual rights. This radical turn in the ways that jurists conceived law had impact also on the normative production that took place in colonial territories. ${ }^{48}$ Legal files were also constitutive of these reform processes that reshaped Portuguese colonial order in Angola. A further analysis of the BDC documents can thus make clearer which were the changes that the form and the materiality of these documents underwent during these decades, thus demonstrating how legal files constituted the rationale of the new characteristics the Portuguese colonial state

\section{Final Remarks: Form and Materiality in the Making of Colonial Legal Orders}

In this article, I put forward the argument that looking at documents instead of just looking through them is a methodological concern that historians dealing with legal files and lawsuits should have. The legal files and lawsuits that are part of the BDC collection open up endless research possibilities. Historians can use them to better understand economic relations in the region, issues related to slavery and to the suppression of the slave trade, conflicts between Portuguese and local authorities, families structures, the relationship between criminal convictions and forced labour, among many others. Nevertheless, a more complex analysis of these issues could be possible if we consider the role that formalities and materiality played in shaping these conflicts.

The cases analysed in this article indicate that the intertextuality between legal files and legal books constantly shaped social conflicts when they made their way to courts. In processing social conflicts, judicial institutions comply with reiterated practices created in this process of mutual reference of legal files and legal books. Formal and material requirements thus transform reality and translate social conflicts into a specific legal language. Moreover, people who lived under Portuguese jurisdiction were aware of these reiterated practices and tried to comply with them in order to secure their rights. This way, legal files shaped and defined social actors' agency.

As the BDC collection shows, different kinds of social groups resorted to Portuguese courts in order to claim for rights. By doing so, they acknowledged the legitimacy of colonial institutions and strengthened Portuguese colonialism. ${ }^{49}$ When resorting to Portuguese courts, they had to comply with prescribed formalities and formulae. Actually, even before going to courts, when producing documents in their daily life transactions, people knew that adopting certain material and formal patterns could determine their success in an eventual judicial case. Thus, in the daily life of colonial societies, people engaged with formalities in a way that enabled their pervasive character and reinforced colonial authority. 
Engaging in an analysis that not only considers the content of the legal files of the BDC's collection, but also their formalities and materiality, can add complexity to narratives that focus on colonial structures in West Central Africa. Looking at the legal files of the BDC collection might shed light on how the reiterated procedures they followed enabled the pervasiveness and endurance of colonial practices concerning the administration of justice and the resolution of conflicts. Looking at them might then show us different aspects of the daily making of colonial legal orders. 
1 Mariana Candido: An African Slaving Port and the Atlantic World. Benguela and Its Hinterland, Cambridge 2013.

2 See, for example, the many works of Mariana Candido; and Roquinaldo Ferreira: Cross-Cultural Exchange in the Atlantic World. Angola and Brazil during the Era of the Slave Trade, Cambridge 2012.

3 José Curto / Frank Luce / Catarina Madeira-Santos: The Arquivo da Comarca Judicial de Benguela. Problems and Potentialities, in: Africana Studia 25 (2015), pp. 11-32.

4 The project is led by Juelma de Matos Ñgala (Katyavala Bwila University), Mariana Candido (University of Notre Dame), and Mariana Dias Paes (Max Planck Institute for European Legal History).

5 Some methodological reflections on lawsuits are made in Arlett Farge: Le goût de l'archive, Paris 1989; and María Angélica Corva: Rastreando huellas. La búsqueda de documentos judiciales para la investigación histórica, in: Revista Electrónica de Fuentes y Archivos 6 (2015), pp. 43-65.

6 For example: Benjamin Lawrance / Emily Lynn Osborn / Richard Roberts (eds.): Intermediaries, Interpreters, and Clerks. African Employees in the Making of Colonial Africa, Madison 2006; Martin Chanock: Law, Custom and Social Order. The Colonial Experience in Malawi and Zambia, Cambridge 1985.

7 Marta Lorente (ed.): De justicia de jueces a justicia de leyes. Hacia la España de 1870, Madrid 2007.

8 Jesús Vallejo: El cáliz de plata. Articulación de órdenes jurídicos en la jurisprudencia del ius commune, in: Revista de Historia del Derecho 38 (2009), pp. 1-13; Alejandro Agüero: Las categorías básicas de la cultura jurisdiccional, in: Marta Lorente (ed.): De justicia de jueces a justicia de leyes. Hacia la España de 1870, Madrid 2007, pp. 1958; Carlos Garriga: Orden jurídico y poder político en el Antiguo Régimen, in: Carlos Garriga / Marta Lorente (eds.): Cádiz, 1812. La constitución jurisdiccional, Madrid 2007, pp 43-72.

9 Bibliography on this topic is extensive. Examples of representative works are Pedro Cantisano: Rio de Janeiro on Trial. Law and Urban Reform in Modern Brazil, unpublished PhD thesis, University of Michigan 2018; Pedro Cantisano / Mariana Armond Dias Paes: Legal Reasoning in a Slave Society (Brazil, 1860-1888), in: Law and History Review 36/3 (2018), pp. 471-510; Brian Owensby / Richard Ross: Justice in a New World. Negotiating Legal Intelligibility in British, Iberian, and Indigenous America, New York 2018; Fernanda Domingos Pinheiro: Em defesa da liberdade. Libertos, coartados e livres de cor nos tribunais do Antigo Regime português (Mariana e Lisboa, 1720-1819), Belo Horizonte 2018; Bianca Premo: The Enlightenment on Trial. Ordinary Litigants and Colonialism in the Spanish Empire, Oxford 2017; Rebecca Scott: Social Facts, Legal Fictions, and the Attribution of Slave Status. The Puzzle of Prescription, in: Law and History Review 35 (2017), pp. 9-30; Michelle McKinley: Fractional Freedoms. Slavery, Intimacy, and Legal Mobilization in Colonial Lima, 1600-1700, Cambridge 2016; Aisnara Perera Díaz / María de los Ángeles Meriño Fuentes: Estrategias de libertad. Un acercamiento a las acciones legales de los esclavos en Cuba (1762-1872), La Habana 2015; Waldomiro Lourenço da Silva Júnior: Entre a escrita e a prática. Direito e escravidão no Brasil e em Cuba (c. 1760-1871), unpublished PhD thesis, Universidade de São Paulo 2015; Carolina González Undurraga: Esclavos y Esclavas demandando justicia. Chile 1740-1823. Documentación judicial por carta de libertad y papel de venta, Santiago de Chile 2014; Keila Grinberg: Re-enslavement, Rights and Justice in Nineteenth-Century Brazil, in: Translating the Americas 1 (2013), pp. 141-159; Orián Jiménez Meneses / Edgardo Pérez Morales: Voces de esclavitud
Popayán 2013; Isabela Guimarães Rabelo do Amaral: Resistência feminina no Brasil oitocentista. As ações de divórcio e nulidade de matrimônio no bispado de Mariana, unpublished Master thesis, Universidade Federal de Minas Gerais 2012; Mariana Candido: African Freedom Suits and Portuguese Vassal Status. Legal Mechanisms for Fighting Enslavement in Benguela, Angola (18001830), in: Slavery \& Abolition 32/3 (2011), pp. 447-459; Cristiano Luís Christillino: Litígios ao sul do Império. A Lei de Terras e a consolidação política da Coroa no Rio Grande do Sul (1850-1880), unpublished PhD thesis, Universidade Federal Fluminense 2010; Márcia Maria Menendes Motta: Nas fronteiras do poder. Conflito e direito à terra no Brasil do século XIX, Niterói 2008; Brian Owensby: Empire of Law and Indian Justice in Colonial Mexico, Stanford 2008; Alejandro De la Fuente: Slaves and the Creation of Legal Rights in Cuba. Coartación and Papel, in: Hispanic American Historical Review 87/4 (2007), pp. 659-692; Tamar Herzog: Upholding Justice. Society, State, and the Penal System in Quito (1650-1750), Ann Arbor 2007; Hebe Maria Mattos: Das cores do silêncio. Os significados da liberdade no sudeste escravista (Brasil, séc. XIX), Rio de Janeiro 1998; Sidney Chalhoub: Visões da Liberdade. Uma história das últimas décadas da escravidão na corte, São Paulo 1990. For the analysis of court cases in jurisdictions who were not under the Iberian Empires' rule, see Jessica Marglin: Across Legal Lines. Jews and Muslims in Modern Morocco, New Haven 2016; Bonny Ibhawoh: Imperial Justice. Africans in Empire's Court, Oxford 2013; Ariela Gross: What Blood Won't Tell. A History of Race on Trial in America, Cambridge 2008; Richard Roberts: Litigants and Households. African Disputes and Colonial Courts in the French Soudan (1895-1912), Portsmouth 2005; Natalie Zemon Davis: O retorno de Martin Guerre, Rio de Janeiro 1987.

10 Some examples of works that focus on the types of lawsuits and on the procedures they followed, in Iberian jurisdictions, are Mariana Armond Dias Paes: O procedimento de manutenção de liberdade no Brasil oitocentista, in: Estudos Históricos 29/58 (2016), pp. 339-360; Fernanda Domingos Pinheiro: Transformações de uma prática contenciosa. As `Ações de Liberdade` produzidas em Mariana (1750/69 e 1850/69), in: Locus, Revista de História 17/1 (2011), pp. 253-271; Fernando Martínez Pérez: IInterim apud hispanos،. Mandati de manutenendo y sumarísimos de posesión en la jurisprudencia moderna española, in: Initium 7 (2002), pp. 139180.

11 The claim to look at paperwork instead of just looking through it was made by Ben Kafka: Paperwork. The State of the Discipline, in: Book History 12 (2009), pp. 340-353, at p. 341.

12 For an overview of this literature, see Matthew Hull: Government of Paper. The Materiality of Bureaucracy in Urban Pakistan, Berkeley 2012; and Kafka: Paperwork.

13 Kafka: Paperwork, p. 341.

14 Lisa Gitelman: Paper Knowledge. Toward a Media History of Documents, Durham 2014, pp. 1-20; Hull: Government of Paper, pp. 13-18.

15 Hull: Government of Paper, pp. 18-27.

16 Cornelia Vismann: Files. Law and Media Technology, Stanford 2008, p. XIII.

17 Bruno Latour: The Making of Law. An Ethnography of the Conseil d'Etat, Cambridge 2010, pp. 70-106.

18 There are, however, one lawsuit issued in 1806 , one in 1821 , one in 1832, and one in 1992.

19 For an overview of this literature, see Guida Marques: De Bahia à Luanda, en passant par Goa. Les déclinaisons du gouvernement impérial portugais au XVIIe siècle, in: Nuevo Mundo, Mundo 
Nuevos 18, Debates, online: http://journals.openedition.org/ nuevomundo/72067 (201822. 07. 2019).

20 For example, Flávia Maria de Carvalho: Sobas e homens do rei. Relações de poder e escravidão em Angola (séculos XVII e XVIII), Alagoas 2015; João Figueiredo: A questão das souvidası, ou a disputa entre autoridades civis e militares pelo julgamento de scausas gentílicası na Angola de meados do século XIX, in: Cadernos de Estudos Africanos 30 (2015), pp. 81-104; Ferreira: CrossCultural Exchange, pp. 88-125; Catarina Madeira-Santos: Esclavage africain et traite atlantique confrontés. Transactions langagières et juridiques (à propos du tribunal de mucamos dans l'Angola des XVIIe et XVIIIe siècles), in: Brésil(s). Sciences humaines et sociales 1 (2012), pp. 127-148; Mariana Candido: African Freedom Suits, pp. 447-459.

21 Cristina Nogueira da Silva: Uma justiça sliberak para o Ultramar? Direito e organização judiciária nas províncias ultramarinas portuguesas do século XIX, in: Revista do Ministério Público 27/105 (2006), pp. 165-200.

22 To maps of bureacratic personal circulation in the Portuguese Empire, see Nuno Camarinhas: Justice Administration in Early Modern Portugal. Kingdom and Empire in a Bureaucratic Continuum, in: Portuguese Journal of Social Science 12/2 (2013), pp. 179-193. On the role of lettered jurists and the production of normative knowledge in colonial jurisdictions, see also Nuno Camarinhas: Juízes e administração da justiça no Antigo Regime. Portugal e o Império colonial, séculos XVII e XVIII, Lisboa 2010; João Fragoso / Nuno Gonçalo Monteiro (eds.): Um reino e suas repúblicas no Atlântico. Comunicações políticas entre Portugal, Brasil e Angola nos séculos XVII e XVIII, Rio de Janeiro 2017; Cristina Nogueira da Silva: A construção jurídica dos Territórios Ultramarinos Portugueses no século XIX. Modelos, doutrinas e leis, Lisboa 2017; António Manuel Hespanha: The Legal Patchwork of Empires, in: Rechtsgeschichte - Legal History 22 (2014), pp. 303-314; Catarina Madeira-Santos: Écrire le pouvoir en Angola. Les archives ndembu (XVIIe--XXe siècles), in: Annales, Histoire, Sciences Sociales 64/4 (2009), pp. 767-795; António Manuel Hespanha: Direito comum e direito colonial, in: Panóptica 1/3 (2006), pp. 95-116.

23 Orlando García Martínez / Michael Zeuske: Estado, notarios y esclavos en Cuba. Aspectos de una genealogía legal de la ciudadanía en sociedades esclavistas, in: Nuevo Mundo, Mundos Nuevos 8, Debates, online: http://journals.openedition.org/ nuevomundo/15842 (22. 07. 2019); Guillaume Gaudin, El imperio de papel de Juan Díez de la Calle. Pensar y gobernar el Nuevo Mundo en el siglo XVII, Madrid 2017.

24 On the constitutive role of documents, see Matthew Hull: Documents and Bureaucracy, in: Annual Review of Anthropology 41 (2012), pp. 251-267.

25 Lauren Benton / Lisa Ford: Rage for Order. The British Empire and the Origins of International Law (1800-1850), Cambridge 2016; Latour: The Making of Law; Edward Thompson: Whigs and Hunters. The Origin of the Black Act, London 1977, pp. 258-269.

26 Arquivo Nacional de Angola, códice 7182.

27 It is still not possible to present quantitative data on people who were parties on the lawsuits stored in the BDC. Data on gender and parties names will be available in the publication of the collection's catalogue.

28 Mariana Candido: African Freedom Suits, pp. 447-459.

29 On the engagement of African population with written documents, see for example Madeira-Santos: Écrire le pouvoir en Angola, pp. 767-795; Catarina Madeira-Santos / Ana Paula Tavares: Africae Monumenta. A apropriação da escrita pelos africanos, Lisboa 2002.
30 Hull: Government of Paper. On the engagement of Africans on the production of written administrative documentation, see MadeiraSantos: Écrire le pouvoir en Angola. On the usage of written documents by slaves and freedpersons in Atlantic jurisdictions, see Jean Hébrard / Rebecca Scott: Freedom Papers. An Atlantic Odyssey in the Age of Emancipation, Cambridge 2014.

31 Benguela District Court, 1866, Autos cíveis de depósito de duas libertas de nomes Bibiana Catumbo, e Theresa Caleço, a requerimento do Curador dos escravos e libertos.

32 Quinpunduca did not speak Portuguese. Benguela District Court, 1866, Autos cíveis de depósito de duas libertas de nomes Bibiana Catumbo, e Theresa Caleço, a requerimento do Curador dos escravos e libertos, p. 24.

33 António Manuel Hespanha: Form and Content in Early Modern Legal Books. Bridging the Gap Between Material Bibliography and the History of Legal Thought, in: Rechtsgeschichte - Legal History 12 (2008), pp. 12-50.

34 António Manuel Hespanha: Como os juristas viam o mundo, 1550 1750. Direitos, estados, pessoas, coisas, contratos, ações e crimes, Lisboa 2015.

35 A list of legal books that circulated in Lusophone Jurisdictions from the $16^{\text {th }}$ to the $19^{\text {th }}$ century can be found in Candido Mendes de Almeida: Codigo philippino ou ordenações e leis do Reino de Portugal recopiladas por mandado d'El-Rey D. Philippe I, volume 1, Rio de Janeiro (1870), pp. XLVII-LXII. For a discussion on the role of legal books in shaping normative orders during the Early Modern period, see Laura Beck Varela: `Memoria de los libros que son necesarios para pasarı. Lecturas del jurista en el siglo XVI ibérico, in: Cuadernos del Instituto Antonio de Nebrija - Revista de Historia de Universidades 21/2 (2018), pp. 227-267; Gustavo César Machado Cabral: Literatura jurídica na Idade Moderna. As decisiones no Reino de Portugal (séculos XVI e XVII), Rio de Janeiro 2017; Laura Beck Varela: The Diffusion of Law Books in Early Modern Europe. A Methodological Approach, in: Massimo Meccarelli / María Julia Solla Sastre (eds.): Spatial and Temporal Dimensions for Legal History. Research Experiences and Itineraries, Frankfurt am Main 2016, pp. 195-239.

36 On the materiality of legal books during the Early Modern period, see Hespanha: Form and Content in Early Modern Legal Books.

37 Gustavo César Machado Cabral: Pegas e Pernambuco. Notas sobre o direito comum e o espaço colonial, in: Revista Direito e Práxis 9/2 (2018), pp. 697-720; Otto Danwerth: La circulación de literatura normativa pragmática en Hispanoamérica (siglos XVIXVII), in: Thomas Duve (ed.): Actas del XIX Congreso del Instituto Internacional de Historia del Derecho Indiano, vol. 1, Madrid 2017, pp. 359-400.

38 Another well-known edition of Caminha's book was the one made in 1764 by lawyer João Martins da Costa. Gregorio Martins Caminha: Tratado da forma dos libellos, das allegações judiciaes, do processo do juizo secular, e ecclesiastico, e dos contratos, com suas glossas, do licenciado Gregorio Martins Caminha. Reformado de novo com addiçoens, e annotaçoens copiosas das Ordenações novas do Reyno, leys de Castella, e modernos, e outras fórmas de libellos, petições, e allegações judiciaes, como Processo do Tribunal da Legacia, e das revistas. Compostas pelo doutor Joaõ Martins da Costa, Coimbra (1764); José Homem Corrêa Telles: Formulario de libellos e petições summarias á imitação do Formulario de Gregorio Martins Caminha. Accomodado á nova reforma de 21 de maio de 1841 , Coimbra (1869). Corrêa Telles' works were widespread in $19^{\text {th }}$ century Brazil and are also present in the BDC collection.

39 Arquivo Nacional de Angola, caixa 2736. 
40 Benguela District Court, 1858, Autos cíveis de revindicação, Autor Manuel Cassador, do distrito da Catumbella, ré Dona Julia Martins de Sant'Anna, pp. 4-5.

41 Kafka: Paperwork, p. 347.

42 Nogueira da Silva: A construção jurídica dos Territórios Ultramarinos; Nogueira da Silva: Uma justiça 'liberal' para o Ultramar?

43 1888, Autos civeis de justificação de posse em que é Justificante Julianna Botelho de Vasconcellos proprietaria e residente nesta cidade de Benguella. 1889, Autos civeis de justificação de posse em que é requerente e Justificante Domingos Sebastião de Barros proprietario e residente no concelho da Catumbella. 1892, Autos cíveis de mera justificação em que é Justificante José Augusto Rodrigues Silva e Justificados O Ministério Público e incertos. 1893, Autos civeis de justificação de mera posse em que é Justificante Joaquim d'Oliveira Barbosa Justificados M. P. e incertos. 1894, Autos civeis de justificação de mera posse entre partes Justificante Jozé Caetano da Silva, proprietario rezidente na Catumbella. 1897, Autos civeis para justificação de posse, Justificante Caetano José Travessa, Justificados Os Incertos. 1899, Autos de justificação de mera posse, Autor Domingos Antonio de Rezende. 1899, Autos de justificação de Mera Posse, Justificante D Francisca Gusmão do Rego. 1899, Acção de justificação, Justificante a firma commercial d'esta praça Eduardo Guedes \& Ca. 1899, Autos de justificação de mera posse, Author Bernardino Gomes Pereira, Os incertos. 1900, Autos civeis de justificação, Justificante Luiz Manoel Marques, Justificados o Ministério Público e Incertos. 1900, Autos civeis de justificação, Justificante a firma Eduardo Guedes \& Ca, Justificados O Ministério Público e Incertos. 1900, Autos civeis de justificação, Justificante Eduardo Guedes \& Ca. 1900, Autos de justificação de mera posse, Justificante Pretres Kamerman, Justificados o Ministério Público e incertos. 1900, Autos civeis de justificação, Justificante a firma Eduardo Guedes \& Ca, Justificados O Ministério Público e Incertos. 1900, Autos de justificação mera posse, Justificante Matheus dos Santos Candeas, Justificados Ministerio Público e Incertos. 1901, Autos civeis vindos da Relação de Loanda, Recorrente Desirée Lourenço Eduardo Braga, Recorridos Ministério Público e incertos. 1901, Autos de justificação de mera posse, Justificante Joaquim Fernandes Barrena, Justificados O Ministério Público e Incertos. 1901, Autos de justificação de mera posse, Justificante Joaquim José Francisco Ribeiro, Justificados O Ministério Público e Incertos. 1902, Autos civeis de justificação, Mello, Santos \& Compa, Requeridos M. Público e incertos. 1902, Autos de justificação de mera posse, Requerente Anthero Gavino do Rego, Requerido O M. P. e incertos. 1902, Acção para justificação de posse, Justificante A Firma Conceição \& Coutinho da Catumbella, Justificados O M. Público e incertos. 1903, Autos de justificação de mera posse, Justificante João de Sousa Honrado e mulher Maria da Conceição Reis Honrado, Justificados O Ministério Público e Interessados incertos. 1903, Autos de justificação de mera posse, Requerente Simões Dias \& Paula, Requerido O Ministério Público e incertos. 1903, Autos de justificação de mera posse, Justificante Cardoso \& Barros, Justificados O Ministério Público e incertos. 1903, Justificação para mera posse, Requerentes Salomão Bendrau e Manoel Joaquim de Carvalho, da Catumbella, Requeridos M Público e incertos. 1904, Autos de justificação de mera posse, Justificante Carlos Rebello de Mattos, Justificados O Ministério Público e interessados incertos. 1904, Autos de justificação de mera posse, Requerente Alfredo d'Almeida Dias, Requerido O Ministério Público e incertos. 1904, Autos de justificação de mera posse, Justificante Antonio José Barbosa, Justificados O Ministério Público e Incertos. 1904, Autos de justificação de mera posse, Requerente Manoel Antonio da Costa, Requerido O Ministério Público e Incertos. 1904, Autos de justificação de mera posse, Requerente Joaquim Marques Pires, Requerido O Ministério Público e incertos. 1907, Autos de justificação de mera posse, Justificante Francisco Ferreira Amaro, Justificados Ministério Público e incertos. 1907, Autos de justificação de méra posse, Justificante Luiz de Mattos Coelho, Justificados o M Público e Incertos. 1907, Autos de justificação de méra posse, Justificante Felisberto Guedes de Souza, Justificados O Ministerio Público e Incertos. 1907, Autos de justificação de mera posse, Justificante Silva Ribeiro e Companhia, Justificado O Ministério Público e Incertos. 1907, Autos de justificação de méra posse, Justificante Domingos Fancony Moura, Justificados O Ministério Público e Incertos. 1908, Autos de justificação de mera posse, Justificante Antonio José Barboza solteiro maior commerciante do concelho do Bihe, Justificados o Ministério Público e incertos. 1908, Justificação de mera posse, Justificante Antonio Pereira Baptista Guimarães. 1918, Justificação de mera posse, Acacio Ribeiro da Silva. 1919, Autos de justificação de mera posse, Justificante Manoel da Costa morador no Macculo, Justificados o M. Público e incertos.

44 Mariana Armond Dias Paes: Escravos e terras entre posses e títulos. A construção social do direito de propriedade no Brasil (18351889), unpublished PhD thesis, Universidade de São Paulo 2018.

45 Dias Paes: Escravos e terras entre posses e títulos; Juan Carlos Garavaglia / Pierre Gautreau (eds.): Mensurar la tierra, controlar el territorio. América Latina, siglos XVIII-XIX, Rosario 2011.

46 Codigo Civil Portuguez: approvado por carta de lei de 1 de julho de 1867, Lisboa (1868), p. 98.

47 Benguela District Court: 1894, Autos civeis de justificação de mera posse entre partes Justificante Jozé Caetano da Silva, proprietario rezidente na Catumbella; 1897, Autos civeis para justificação de posse, Justificante Caetano José Travessa, Justificados Os Incertos; 1899, Autos de justificação de mera posse, Autor Domingos Antonio de Rezende; 1899, Autos de justificação de Mera Posse, Justificante D Francisca Gusmão do Rego; 1899, Acção de justificação, Justificante a firma commercial d'esta praça Eduardo Guedes \& Ca; 1900, Autos civeis de justificação, Justificante Luiz Manoel Marques, Justificados o Ministério Público e Incertos; 1900, Autos civeis de justificação, Justificante a firma Eduardo Guedes \& Ca, Justificados O Ministério Público e Incertos; 1900, Autos civeis de justificação, Justificante Eduardo Guedes \& Ca; 1900, Autos de justificação de mera posse, Justificante Pretres Kamerman, Justificados o Ministério Público e incertos; 1900, Autos civeis de justificação, Justificante a firma Eduardo Guedes \& Ca, Justificados O Ministério Público e Incertos; 1901, Autos civeis vindos da Relação de Loanda, Recorrente Desirée Lourenço Eduardo Braga, Recorridos Ministério Público e incertos; 1901, Autos de justificação de mera posse, Justificante Joaquim Fernandes Barrena, Justificados O Ministério Público e Incertos; 1901, Autos de justificação de mera posse, Justificante Joaquim José Francisco Ribeiro, Justificados 0 Ministério Público e Incertos; 1902, Autos civeis de justificação, Mello, Santos \& Compa, Requeridos M. Público e incertos; 1902, Autos de justificação de mera posse, Requerente Anthero Gavino do Rego, Requerido O M. P. e incertos; 1902, Acção para justificação de posse, Justificante A Firma Conceição \& Coutinho da Catumbella, Justificados O M. Público e incertos; 1903, Autos de justificação de mera posse, Justificante João de Sousa Honrado e mulher Maria da Conceição Reis Honrado, Justificados O Ministério Público e Interessados incertos; 1903, Autos de justificação de mera posse, Requerente Simões Dias \& Paula, Requerido O Ministério Público e incertos; 1903, Autos de justificação de mera posse, Justificante 
Cardoso \& Barros, Justificados O Ministério Público e incertos; 1903, Justificação para mera posse, Requerentes Salomão Bendrau e Manoel Joaquim de Carvalho, da Catumbella, Requeridos M Público e incertos; 1904, Autos de justificação de mera posse, Justificante Carlos Rebello de Mattos, Justificados O Ministério Público e interessados incertos; 1904, Autos de justificação de mera posse, Requerente Alfredo d'Almeida Dias, Requerido O Ministério Público e incertos; 1904, Autos de justificação de mera posse, Justificante Antonio José Barbosa, Justificados O Ministério Público e Incertos; 1904, Autos de justificação de mera posse, Requerente Manoel Antonio da Costa, Requerido O Ministério Público e Incertos; 1904, Autos de justificação de mera posse, Requerente Joaquim Marques Pires, Requerido O Ministério Público e incertos; 1907, Autos de justificação de mera posse, Justificante Francisco Ferreira Amaro, Justificados Ministério Público e incertos.

48 Nogueira da Silva: A construção jurídica dos Territórios Ultramarinos.

49 See, for example, Candido: African Freedom Suits. 


\section{Abstract}

Much has been said on the role of judges, legal officials, and courts in the making of colonial regimes. Nevertheless, historiography lacks specific methodological reflections on lawsuits in the Iberian Empires. In order to raise some methodological issues concerning lawsuits as primary sources, I argue that historians could also engage with legal files by looking at instead of just looking through them. In this sense, I seek to establish a dialogue with discussions that anthropologists and social scientists put forward concerning the role of documents as constitutive of bureaucracies and administrative institutions. In order to do so, I will focus on specific aspects of the Benguela District Court collection of legal files.

\section{About the Author}

Mariana Dias Paes is a Research Group Leader at the Max-Planck-Institute for European Legal History and at the Cluster of Excellence 'Beyond Slavery and Freedom،. She received her MA in Law from the University of São Paulo (2014) and her PhD in Law from the same University (2018). Her PhD was funded by a Doctoral Contract at the Max-PlanckInstitute for European Legal History. Her research interests are legal history, slavery, and property in Brazil and Angola during the $19^{\text {th }}$ century. She has published on these issues in Portuguese, Spanish, English, and French. Her most recent book is entitled Escravidão e Direito: o estatuto jurídico dos escravos no Brasil oitocentista, 1860-1888 (2019). 